\title{
SOME ASPECTS OF PASTURE PRODUCTION AND UTILISATION IN SOUTHLAND
}

A. J. HARRIS, Scientific Officer, Grasslands Division, Department of Scientific and Industrial Research, Gore

The Agricultural and Pastoral Statistics for the 1958-59 season show that at 31 January 1959 the total number of cattle per 100 sheep shorn in Southland was 3, while in the North and South Auckland districts combined the figure was 42. This paper will, then, refer to pastures used for grazing sheep.

Relevant details concerning the climate of the area, summarised from meteorological records from 195'2-59, are presented in Table 1.

\begin{tabular}{|c|c|c|c|c|c|c|c|c|c|}
\hline \multirow[b]{3}{*}{ Station } & \multicolumn{5}{|c|}{ TABLE । } & \multirow{2}{*}{\multicolumn{4}{|c|}{$\begin{array}{l}\text { Points Precipitation } \\
\text { per rain day }\end{array}$}} \\
\hline & \multicolumn{5}{|c|}{$\begin{array}{l}\text { Points } \\
\text { Precipitation }\end{array}$} & & & & \\
\hline & & Spr. & Sum. & Aut. & Win. & Spr. & Sum. & Aut. & Win. \\
\hline Gore & & 787 & 940 & 969 & 692 & 19 & 23 & 22 & 15 \\
\hline Invercargill & & 938 & 994 & 1,179 & 1,011 & 20 & 22 & 25 & 18 \\
\hline O tautau & $\ldots$ & 915 & 943 & 1.318 & 1,097 & 24 & 25 & 31 & 24 \\
\hline Pebbly Hills & & 854 & 972 & 1,029 & 950 & 19 & 22 & 21 & 19 \\
\hline
\end{tabular}

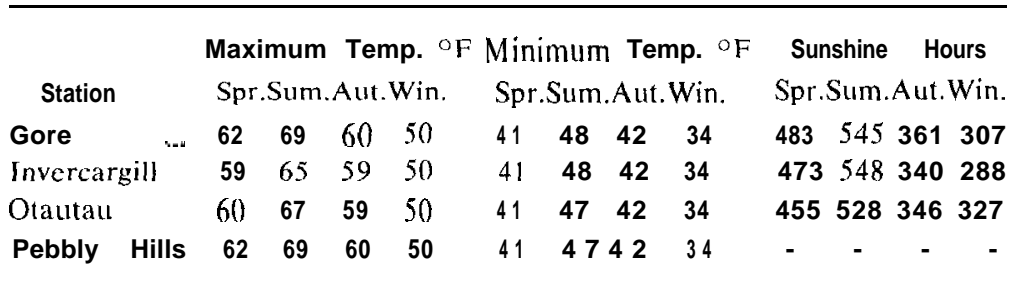

While rainfall is fairly evenly distributed throughout the year at each station, there are differences between stations in total rainfall; and Otautau 43 in. per annum. Otautau has somewhat fewer rains for instance, Gore 34in., Invercargill 41 in., Pebbly Hills 38in., cant. Mean maximum temperatures are equable, while the mean days than the others, with heavier showers, but this is not signifitemperature range is about $20^{\circ} \mathrm{F}$ and differences between stations 
are small. There arc virtually no differences in sunshine hours between stations,

Production from pastures in Southland, as in most regions of New Zealand, exhibits a very definite seasonal rhythm. Potential seasonal production (that is, production where soil conditions, nutrient status, pests, and diseases are not limiting) for various species at different localities has been shown by Mitchell ( 1956). In this region lack of light and low winter temperatures are the major limiting factors of the climate. Actual seasonal production data at Gore for five grass species sown as simple mixtures and given a similar rotational grazing management have been presented by Lambert (1954). An extract of these data is presented in Figure 1.

FIG. 1

SEASONAL YIELDS FROM SIMPLE GRASS \& CLOVER MIXTURES $1.9 .54 \quad-31.8 .55$ Ib DRY MATTER PER ACRE

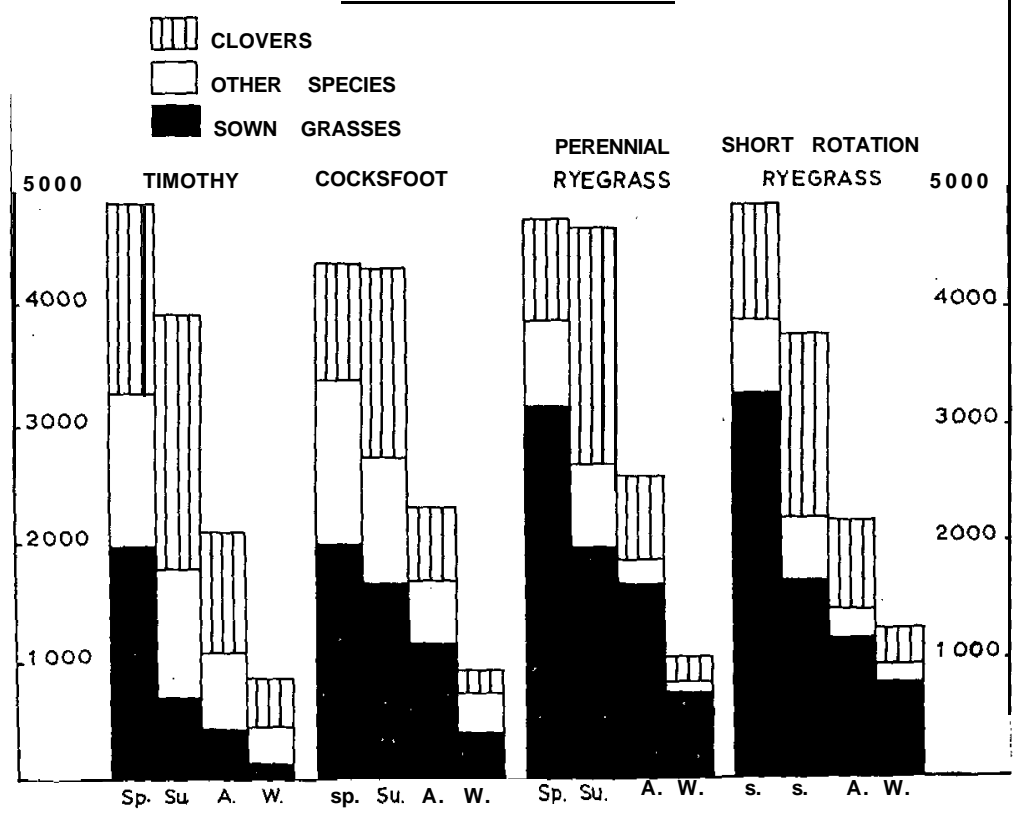

Total annual production is very similar, while differences in production between seasons are obvious. It is equally apparent that if stocking rates were to be based on this pattern of growth, buying and selling would cause such gluts and shortages on the market that the whole system would break down. When the nutri- 
tion of the pregnant ewe is considered, the problem of equating available feed to animal requirements becomes even morc complex.

For convenience, a division can be made into four periods which are to some extent arbitrary, for they arc all inter-related and what is done in one period may affect what can be done in the next, or even nine months hence. These periods are:

1. Lactation.

2. Weaned.

3. Flushing.

4. Pregnancy.

Of these, it is often considered that the pregnancy period is the most critical, for much of it coincides with winter. Pasture production is at its lowest and obviously some supplementary feeding is required. This has traditionally been provided by brassica crops and hay, although hay only may be used.

I propose to discuss a trial run at Grasslands Division, Gore, to illustrate the integration of utilisation with pasture production. The application is to fat Iamb farming.

\section{Experimental}

The trial consisted of six self-contained units each of one acre run as fat lamb farms buying annual draft ewes. It began in February 1957 after a settling-down period, with the objectives of comparing the suitability of hay as a winter feed with the conventional brassica crop (swede turnips and chou moellier) plus some hay. This was carried out at three rates of stocking: Low (6 ewes), Medium (8 ewes), and High (10 ewes, reduced to 9 in 1959-60). It was felt that at the higher stocking rates any benefit of a particular system would be apparent. At the same time, determination of the optimum stocking rate would be useful, for McMeekan ( 1956) has pointed out that an increase of stocking rate is the most potent method of increasing production. All units were setstocked from lambing to weaning with a rotational grazing system during the remainder of the year, as previous work (Lambert, personal communication) had indicated that set stocking gave the best lamb fattening conditions, while the rotational grazing allowed for some elasticity in management. One sixth of an acre was rencwed each year, either through crop in the appropriate units or from old grass to new pasture. The number of lambs running with the ewes was approximately 133 per cent. Normal amounts of supcrphosphatc, D.D.T., and lime were applied.

\section{R esults}

Dry matter consumption for each of the four periods is summarised in Table 2. 
TABLE 2 -DRY MATTER CONSUMPTION

3 Year Average 1957-60

\begin{tabular}{|c|c|c|c|c|c|c|c|}
\hline \multirow{4}{*}{$\begin{array}{l}\text { Period } \\
\text { Lactation }\end{array}$} & \multicolumn{7}{|c|}{ Low } \\
\hline & \multicolumn{4}{|c|}{ Crop } & \multicolumn{3}{|c|}{ Hay } \\
\hline & Pasturc & $\mathrm{H}$ a y & $\mathrm{Crop}$ & Tot a 1 & Pastur & $\mathrm{c} \mathrm{Hay}$ & Total \\
\hline & 3,909 & & & 3,909 & 3,497 & & 3,497 \\
\hline (Mid Sept.-Nov.) & & & & & & & \\
\hline $\begin{array}{c}\text { Weaned } \\
\text { (Dec.-Feb.) }\end{array}$ & 1,841 & & & 1,841 & 1,809 & & 1,809 \\
\hline $\begin{array}{l}\text { Flushing } \\
\text { (Mar.-April) }\end{array}$ & 1,091 & & & 1,091 & 1,214 & & 1,214 \\
\hline \multirow{2}{*}{$\begin{array}{c}\text { Pregnancy } \\
\text { (May-mid-Sept.) }\end{array}$} & 1,157 & 415 & 748 & 2,320 & 1,565 & 735 & 2,300 \\
\hline & & & Total & 9,161 & & Total & 8,820 \\
\hline & \multicolumn{7}{|c|}{ MEDIUM } \\
\hline $\begin{array}{c}\text { Lactation } \\
\text { (Mid-Sept.-Nov.) }\end{array}$ & 3,773 & & & 3,773 & 3,407 & & 3,407 \\
\hline $\begin{array}{c}\text { Weaned } \\
\text { (Dec.-Feb.) }\end{array}$ & 1,969 & & & 1,969 & 2,146 & & 2,146 \\
\hline $\begin{array}{l}\text { Flushing } \\
\text { (Mar.-April) }\end{array}$ & 1,548 & & & 1,548 & 1.364 & & 1,364 \\
\hline \multirow{3}{*}{$\begin{array}{l}\text { Pregnancy } \\
\text { May-mid-Sept.) }\end{array}$} & $1,31 \mathrm{I}$ & 449 & 800 & 2,560 & 1,728 & 1,067 & 2,795 \\
\hline & & & Total & 9,850 & & Total & 9,7 I2 \\
\hline & \multicolumn{7}{|c|}{$\mathrm{HIGH}$} \\
\hline $\begin{array}{c}\text { Lactation } \\
\text { (Mid-Sept.-Nov.) }\end{array}$ & 3,641 & & & 3,641 & 3,235 & & 3,235 \\
\hline $\begin{array}{c}\text { Weaned } \\
\text { (Dec.-Feb.) }\end{array}$ & 2,183 & & & 2,183 & 2,527 & & 2,527 \\
\hline $\begin{array}{c}\text { Flushing } \\
\text { (Mar.-April) }\end{array}$ & 1,717 & & & 1,717 & 1,864 & & 1,864 \\
\hline \multirow{2}{*}{$\left(\begin{array}{l}\text { Pregnancy } \\
\text { May-mid-Sept.) }\end{array}\right.$} & 1,381 & 800 & 854 & 3,035 & 1.597 & 1,383 & 2,980 \\
\hline & & & Total & 10,576 & & Total & 10,606 \\
\hline
\end{tabular}

\section{The Lactation Period}

This coincides, in the case of the trial at Gore, with a period from about mid-September to the beginning of Dcccmber. It is in total the period of maximum growth, but frequently with a low period during September and October and with a subsequent flush period in November and December. I consider October to be quite a difficult month, for consumption is largely based on production, without a great deal of benefit from carried-over supplies of feed, as can occur in September.

This is the period of maximum consumption, and the allimportant factor is the amount of feed produced from pasture. 
Obviously therc arc limits to the yield that can bc expected, and if everything else is in order, climate (or weather in the short term) is going to impose this limitation. The only means of equating production and consumption, then, is by having a stocking rate which is near optimum.

Stocking rate affects, firstly, body weight of the ewe. At the low rate of stocking thcrc is a buffer against shortages in October and body weight remains fairly constant, but at the medium and high rates thcrc is a steep drop in body weight, the rate of dccrcasc becoming more apparent as stocking rate goes up. There is, secondly, an effect on milk supply. Because the lamb is largely dependent on milk for about the first six weeks, and because checks to the rate of growth must where possible be avoided, this is quite detrimental. Table 3 illustrates for the 1959-60 season the influence of rate of stocking on meat production from the units.

\begin{tabular}{|c|c|c|c|c|c|c|}
\hline \multicolumn{7}{|c|}{ TABI E 3} \\
\hline & \multicolumn{2}{|c|}{6 EWES } & \multicolumn{2}{|c|}{8 EWEs } & \multicolumn{2}{|c|}{9 EWLS } \\
\hline No. Stock Graded & Crop & $\mathrm{H}$ a $\mathrm{y}$ & Crop & H a y & Crop & Hay \\
\hline Fat lambs ( 1st Draft) - & 6 & 4 & 3 & 3 & 3 & 5 \\
\hline Fat lambs (2nd Draft) & 2 & 4 & 一 & - & - & - \\
\hline Storc lambs & & - & 8 & 8 & 9 & 7 \\
\hline Ewes to works & 6 & 6 & 5 & 4 & 4 & 4 \\
\hline Cull cwes & & - & 3 & 4 & 5 & 5 \\
\hline
\end{tabular}

Considering the pasture again: at low rates of stocking during November and December it is a matter of maintaining quality of the feed. This has been done by withdrawing paddocks in midNovember and making hay just before Christmas. If stocking ratc is too low, the surplus becomes apparent earlier, as shown by the large degree of selective grazing which takes place, and either the quality of the feed is allowed to drop or an attempt is made to make hay in early December, frequently with disappointing results. If, on the other hand, stocking rate is too high, it is almost impossible to make hay in December, for the growth produced in November is readily consumed.

In summary, what takes place in this period affects what can take place for the remainder of the year. It is obviously good practice to obtain a high percentage of lambs from the mothers at an early date, concomitant with high returns of meat per acre as an insurance against drought and provision of hay in the weaned period. 


\section{The Weaned Period}

This period coincides with the months of December, January, and February under the system we have adopted. It is a period when pasture production exceeds stock requirements, or should, but very obviously this is conditioned by stocking rate which determines largely how many lambs remain to bc fattened, how many ewes require good feeding to enable them to be sold, and how many require only sufficient food to maintain them so that they do not become over-fat. By the same token what has occurred in the previous period determines how much pasture can be withdrawn from grazing and conserved as hay. For example, in the hay only unit at 6 ewes per acre 2,500 $\mathrm{lb}$ of hay were conserved in 1957-58 and $8001 \mathrm{~b}$ in 1958-59, while the consumption figures were 570 and $1,450 \mathrm{lb}$ respectively. A surplus of $1,280 \mathrm{lb}$ of hay was left at the end of these two seasons. In contrast, at the high rate of stocking 1,290 lb were conserved in 1957-58 while 1,480 lb were consumed. In 1958-59 only $430 \mathrm{lb}$ were conserved while the consumption figure was $1,570 \mathrm{lb}$, a deficit in the first ycar of $190 \mathrm{lb}$ and $1,140 \mathrm{lb}$ in the second year, or a total deficit over the two seasons of $1,330 \mathrm{lb}$.

Two factors are operable here:

1. The high number of lambs requiring to be carried on after the first draft, as well as the high proportion of ewes requiring fattening to bring them to marketable condition at the high rate of stocking. As a comparison, the majority of lambs were produced fat from the mothers, and ewes required a minimum of food at the low rate.

2. This above affected time of shutting for hay, for at the high rate hay could not be conserved until late in the season and insufficient could be made. Making hay later than February is risky, and conscquently, with some paddocks being closed in January, yields were low.

Hay aftermath seems a valuable material on which to fatten any lambs remaining, and this can be achieved where stocking rate is not too high. Production from this source can be stored and carried over to the following period.

\section{The Flushing Period}

Feed for flushing has been derived from growth made at the latter end of the period just described and stored over to at least the extent of providing a foundation on which further supplies can be built. The feed requirements of the newly brought-in ewe flock are low until some 2-3 weeks before the rams are put out, which in our case is during the last week of March, By then a 
substantial reserve of feed has been built up and these pastures can be grazed on a rotational basis, taking care not to bare them down.

Because of production in autumn and a reserve of feed built up previously, there tends to be some feed which is surplus to requirements. This has been conserved in situ as autumn-saved pasture. Usually pastures are closed over the period late March to early April. The aim has been to conserve about one third of each unit, although at the high rate of stocking in a favourable autumn this has been extended to as much as half. This provides a sufficiency, and even over-supply, at the low rate of stocking, but at the high rate, because of the high pressure of grazing (a resultant from the lactation period), it is thought that half the unit is needed to give an ideal quantity of this feed.

As a general recommendation, it is sound practice to shut only those pastures which are vigorous, with a good balance between grass and clover, and which contain a high proportion of shortrotation ryegrass. This latter has the ability to grow in the colder periods of the year and hence can produce a good bulk of feed during April.

Artificial nitrogenous fertilisers have been used, at varying rates, with no little success. The use of these fertilisers has been good insurance against frost damage, and with the use of as little as $1 \frac{1}{4}$ cwt of sulphate of ammonia applied when the pasture is closed in April, frost burn has becn confined to about one inch at the tips of the leaves, despite successive severe frosts. The aim has been to produce feed of about 6 to $9 \mathrm{in}$. high, and to achieve this the combinations of time of shutting and nitrogen application have been manipulated to the best advantage.

\section{The Pregnancy Period}

This is the period of lowest production, hence utilisation of feed, whether from supplements or from pasture, must be based on the requirements of the ewe. The level of nutrition during the first three months of pregnancy has very little effect on the growth of the developing lamb, whereas the level of feeding in the latter stages has a profound effect on birth weight and health of the cwe. This is clearly explained by Wallace (1959).

WC have adopted the system of reducing the intake of the ewes in May after the rams have been taken out, by confining them to one paddock which can be termed the concentration paddock or run-off or stamping paddock according to one's preference. No matter what name it is given it has the advantage of ( 1 ) allowing tight rationing of feed to be adhered to and (2) it prevents poaching over much of the area. The restricted level of feeding is con- 
tinued through June and until six weeks beforc lambing begins, when the level is gradually raised in quantity and quality. Table 4 illustrates the method of feeding for this period.

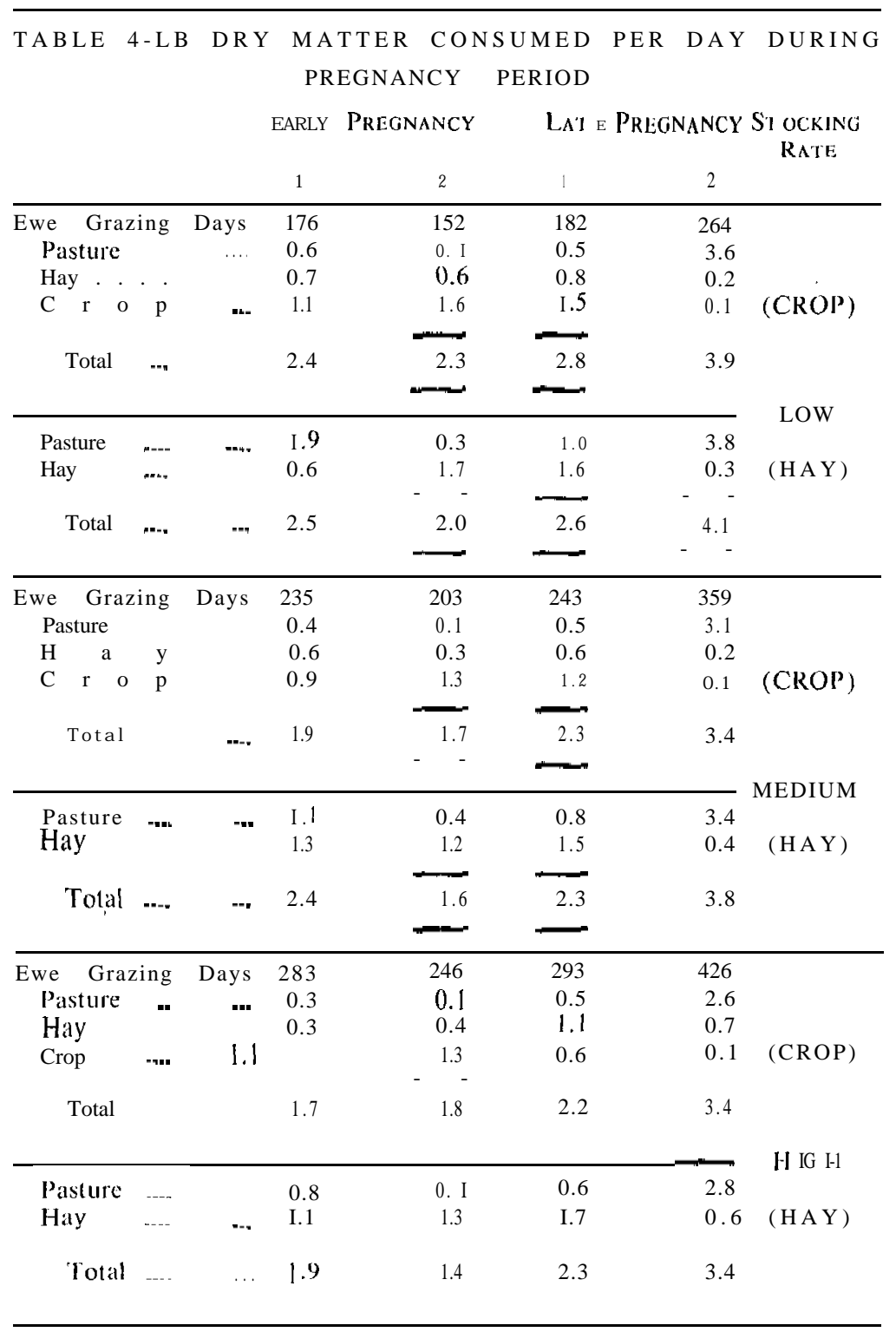

Several interesting points arise from this: 


\section{The Level of Nutrition}

If the total dry matter consumption is considered, the severc rationing imposed in the early period is apparent. In all but one case, intake for the first part of the early period is higher than the second, being mainly contributed by pasture. The explanation is that a small fraction of this is a carry-over from the flushing period; some regrowth in the stamping paddock has provided the remainder. However, during the second part total dry matter consumption is down to as low as $1.4 \mathrm{lb}$ at the high rate of stocking and rises no higher than $2.3 \mathrm{lb}$ at the low rate. During the first part of the late period the ration has been increased to allow a consumption of 2.2 at a high stocking rate and up to 2.8 at six ewes per acre. These figures do not appear much higher than those of the previous period, but until the mid-point of late period I feeding was only slightly better than previously, but after the mid-point there was a definite risc. Thus for IA I would estimate a figure of $2.5 \mathrm{lb}$ for the first half and $3.2 \mathrm{lb}$ for the second half of this-period-to-be-reasonable. However, the figures as presented show the trend.

\section{The Use of Pasture}

Most animal nutritionists agree that an increase in quality as well as quantity of the ration during the vital four to six weeks before lambing is necessary. At Gore we have made use of autumn-saved pasture to carry this out and the table demonstrates how the type of feed changes with time. On the average, over-all rates of stocking, the ration of pasture changes from approximately $0.2 \mathrm{lb}$ initially to $3.2 \mathrm{lb}$ per day in the final period. The ration of hay or crop plus hay varies inversely; thus the emphasis changes from a predominantly maintenance type of feed to one of high nutritive value.

The method of rationing must ensure that consumption is steadily increased. We have used what is termed the clock system, where sheep are put on for a specified time each day, which increases gradually as lambing approaches, and also strip grazing with an electric fence. It. is important that large areas are not used, for much valuable feed can be wasted by trampling. Both systems work well.

\section{Stocking Rate}

As one would expect, the rate of stocking has a profound effect on what can be achieved under this system. Not only does it affect the amount of feed which can be offered in the initial stages, but it also conditions what can bc donc in the later stages. The table shows that the amount of pasture, and in fact total dry 
matter, in the final period in the low and medium stocked units is rather similar (about $3.5 \mathrm{lb}$ ), while at the high rate of stocking the amount of pasture fed is much reduced. This smaller ration of pasture available for use reflects the stress placed on these units; the stress is there initially in summer and autumn and carried over into the period under discussion. Nevertheless, even at this rate the feeding system has worked, for the number of ewes lost during the 195940 season from pregnancy toxaemia was nil while the weight of lambs at birth averaged $8 \mathrm{lb}$ each for twins and $11 \mathrm{lb}$ for singles. At six ewes per acre for the same season ewe losses were nil and birth weights were $10 \mathrm{lb}$ each for twins and $12 \mathrm{lb}$ for singles,

I intend digressing from this experimental work to the general farmer picture as 1 see it, One must always take care in making generalisations to specify that there are exceptions, but unfortunately the exceptions. to the picture I will describe are too rare.

How many farmers in this audience have made the statement recently, "The grass seems to be hanging on well, so I'll eat it and keep off the swedes for a while." If this is a representative cross section here, there will be quite a number who have said that. I believe that this concept is wrong. If the grass is growing well get off it and eat the crop of swedes. They will be of more benefit to you early than late. Turnips and hay are maintenance feeds only and are useful in the early part of the period. There were too many crops about this ycar which were wasted because farmers used valuable grass at a time when they could have, and should have, been conserving it.

\section{Conclusion}

Let me dispel any illusions that may have been created that I am advocating low stocking rates. For the purposes of presentation, stocking rates have been referred to as low, medium, and high, but if the actual rates are considered and compared to what may be termed an average stocking rate for the district, one finds one is comparing six ewes per acre with approximately four.

Table 5 provides an illustration of the returns from animal products obtained from each unit, and although there is little difference in the gross figure, because of the cost of replacement ewes there is little advantage in exceeding six ewes per acre. It is my opinion, however, although the point remains to bc proved, that the optimum stocking rate is between six and eight ewes per acre. 
TABLE S-RETURNS FOR ANIMAL PRODUCTS 1959-60

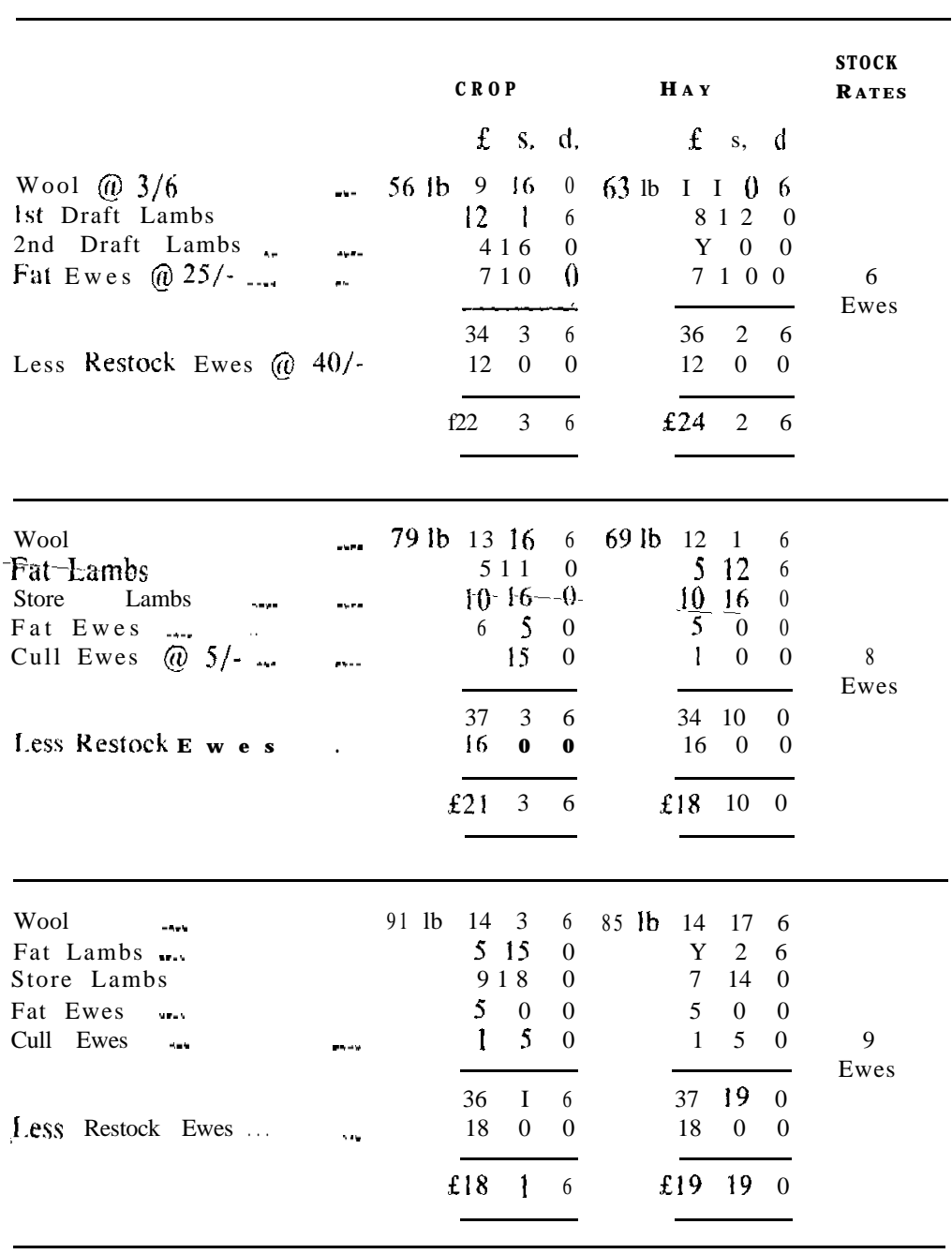

Over the three years of the trial no advantage could be seen for crop as winter feed over hay only or vice versa. Either ration seems quite satisfactory, provided it is treated as a maintenance feed and used at the time outlined previously.

I believe that, in general, production in Southland can contribute more than it is being called on to do and that the means of making more effective use of this production is by better utilisation, an integration of pasture plant and the grazing animal. 


\section{Acknowledgments}

Members of the staff of Grasslands Division, Gore, in particular $\mathrm{Mr} \mathrm{A}$. F. Boyd, have contributed to this paper by technical assistance and discussion. The criticism and advice of Dr P. D. Scars are also gratefully acknowledged.

\section{R eferences}

Lambert, J. P. 1954: The value of pasture species in Otago and Southland, Proc. N.Z. Grassld. Assn. 122-1 31.

Mitchell, K. I. 1956: The influence of light and temperature on the growth of pasture species. Proc. 7th Int. Grassld. Congr. 58-67.

McMeekan, C. P. 1956: Grazing management and animal production. Ibid. 146-1 55 .

Wallace, L. R. 1959: Nutrition of grazing sheep. Proc. N.Z. Grassld. Assn. 86-96.

\section{DISCUSSION}

Comment (Dr P. D. Scars): I am intrigued with differences between Timothy and ryegrass production between those mentioned by Faithful at Winton and at Gore.

A. (W. Faithful): It is due partly to the soil type which is an alluvial deposit at Gore of higher quality than at Winton, and secondly to the better fertiliser treatment at Gore. In Winton there was a particular-l) good growing season for Timothy and therefore a relatively better performance of Timothy at Winton.

Q. What was the fertiliser treatment of the species production trial?

A. Sufficient phosphate and lime used. Grazed at 3 to 4 in. stage down to 1 in. This type of grazing may have been responsible for the simila total yields. At the end of the trial percentage of short rotation ryegrass was high but Timothy was much reduced.

Q. (J. W. Woodcock) : Would you advocate the use of sulphate of ammonia to prevent winter burn, as a general practice?

A. Not as a general practice. However, probably judicial applications are warranted in two cases-for ASP and for a seed crop. But stocking rate must be high to make nitrogen applications economic.

Comment: There has been experience using nitrogen and potash to prevent frost damage. The rates recommended for $\mathrm{HI}$ were $1 \mathrm{cwt}$ potash, $1 \mathrm{cwt}$ nitrogen and $2 \mathrm{cwt}$ superphosphate.

A. There have been no potash responses at Gore but it will have to be watched.

Comment (Dr P. D. Sears): Nitrogen applications on perennial ryegrass and HI have been compared in an early trial at Gore. Nitrogen was applied in spring and autumn. Pastures were summer grazed and as a result of selective grazing where white clover was grazed out of the perennial ryegrass pasture but not out of the HI pasture, a nitrogen response was obtained from the perennial ryegrass in the autumn,

Q. Have you considered using the forage harvester for making silage to level out peaks of pasture production?

A. The trial unit was too small to carry out silage making. There are several ways of levelling out peaks in pasture production, namely silage making, varying stocking rate, using cattle, etc., but we have used stocking rate. 